\title{
The Influence of Newspaper Ownership on the Objectivity of the Coverage of Nigeria's 2015 Presidential Election
}

\author{
Frederick Mordi, MSc \\ Silk Ugwu Ogbu, PhD \\ School of Media and Communication, \\ Pan-Atlantic University, Lagos, Nigeria
}

Doi: 10.19044/esj.2017.v13n32p286 URL:http://dx.doi.org/10.19044/esj.2017.v13n32p286

\begin{abstract}
This paper examines the impact of politician-businessperson-owned (PBO) newspapers on the objectivity of the reportage of the 2015 presidential election in Nigeria, by some selected media organisations. Adopting analysis of documentary evidence as methodology, the study examines the dominant themes of some PBO newspapers during their coverage of the election. This was done with a view to establishing their level of objectivity, which is defined in terms of whether these media organisations gave equitable coverage to all the 26 political parties and their candidates; and their level of compliance with professional ethics. Using gatekeeping theory as main theoretical framework, the paper finds that media owners, and not the editors, appear to be the gatekeepers. The paper recommends proper regulation of media organisations in the country to ensure that they meet stipulated ethical standards.
\end{abstract}

Keywords: Objectivity, Gate-keeping, Newspaper Ownership, Elections, Hate Speech.

\subsection{Introduction}

Perhaps, no other election in Nigeria's recent political history generated as much interest and tension as the 2015 presidential election (Durotoye, 2015). The prediction attributed to John Campbell, a former United States Ambassador to Nigeria, that the country might break up in 2015, heightened anxiety as the election date approached. A history of post-election violence put the nation and the international community on edge (Durotoye, 2015). Many Nigerians stockpiled food, while some of the elites secretly travelled out of the country in anticipation of the worst. Although tensions and the anticipation of conflicts are common during elections in most parts of the 
world, the Nigerian experience was more impactful due to doomsday prophecies on the potential disintegration of the country in 2015.

According to Ibraheem et al (2013), both serving and retired highranking foreign diplomats including the immediate past Secretary of State of the United States, John Kerry; former United Nations Secretary General, Kofi Anan; and former Commonwealth Secretary General, Emeka Anyaoku; all visited the principal actors - then incumbent President Goodluck Jonathan, and the presidential flag bearer of the opposition party and now President of Nigeria, Muhammadu Buhari-to extract a firm commitment from them, to maintain the peace before, during and after the election. These diplomats apparently took this step to forestall possible break down of law and order, after the announcement of the results, as had been the case in the past. Despite these assurances, a lot of mudslinging characterised the electioneering. The two dominant parties in the country - the then ruling Peoples' Democratic Party (PDP), and the main opposition party, the All Progressives Congress (APC), now in power-employed the traditional and social media to prosecute a seeming war of attrition. But the outcome of the election was generally peaceful, positioning Nigeria as a country that is fast attaining political maturity (Owen and Usman, 2015). The presidential election was, in a sense, a test for the nation's fledgling democracy.

It was the first election in which the nation's electoral body, the Independent National Electoral Commission (INEC), would use a permanent voters' card (PVC), an electronic card, to decide the winner of the ballot box (Owen and Usman, 2015). For the first time, also, a sitting president lost an election in a country where incumbency is an important factor in deciding a winner. In addition, it was the first time that the loser in a presidential election would call to congratulate the winner even before the electoral umpire officially announced the results. Typically, losers in some of the previous presidential elections went to court to contest the results. All these contributed to the uniqueness of the election. There were also insinuations that the European Union (EU) may have favoured Buhari above the other presidential candidates during the elections. But Santiago Fisas, the former Chief Observer of the 2015 EU Election Observation Mission (EU EOM), and Member of the European Parliament, described this allegation as baseless. According to the News Agency of Nigeria (NAN), Fisas, who made the clarification in Abuja on October 22, 2017, while giving the EU assessment of the elections, insisted that the EU was more interested in strengthening the democratic process than who became the President of Nigeria.

The interest of this study is to examine the role media ownership played in moulding public opinion during the election. The study makes reference to works of Njemanze and Arogundade (2015), who conducted a detailed analysis of the outcome of the elections. In their research, Njemanze 
and Arogundade (2015, p2) argue that the 'actions or inactions of media professionals can impact positively or negatively on the credibility and fairness of the electoral situation under which people exercise the right to choose.' But there are legislative and institutional frameworks in place that provide practical guidelines on how the media should or should not perform their constitutional role during elections. According to Njemanze and Arogundade (2015) such guidelines are contained in the Electoral Act 2010 (sections 100 and 101), the Nigerian Broadcasting Code (section 5), the Code of Ethics of Journalists in Nigeria and the Nigerian Media Code of Election Coverage. This research also carries out a comparative review of a related study on Nigeria's 2015 elections by Nwammuo et al (2015).

Ultimately, the study will attempt to ascertain if politicianbusinessperson-owned (PBO) newspapers in the country complied with these extant guidelines in terms of their level of objectivity in the reportage of the election. To this do, it will be useful to give a brief background to the study. This will help in contextualising the issues.

\subsection{Background: Categories of Newspaper Ownership in Nigeria}

There are different categories of newspaper owners in Nigeria. The first is made up of papers owned and controlled by the governments. Politicians and businessmen control the second category of newspapers, while some Journalists, who also own newspapers, belong to the third category. However, this study will focus on the PBO newspapers because they are the most challenging for media professionals. According to Ojebode (2013) PBO newspapers are those media outlets that are established by politicians who are also businesspersons. The Nation, whose owner is a politician and businessman, Bola Tinubu, is an example of a PBO newspaper. Some of the other main PBO newspapers in the country include Leadership owned by Sam Nda Isaiah, who contested and lost at the 2015 APC presidential primaries; Daily Sun and New Telegraph, published by Orji Uzor Kalu, a former Governor of Abia State and businessman; and Independent, owned by James Ibori, a former Governor of Delta State, who is also a businessman. Section 36, Subsection 11 of the Nigerian Constitution, states clearly that every person shall be entitled to establish and operate any medium for the dissemination of ideas and opinion. That is the reason there are over 150 newspapers and magazines in Nigeria today.

\subsection{Newspaper Ownership and Editorial Freedom}

Ownership determines to a large extent, media behaviour and performance. Ownership describes the proprietorship rights that an individual, a group, or an institution, exercise over a media house (Omenugha et al, 2013). These rights confer on such proprietors, the power to determine editorial 
viewpoint and content of media organisations. Okunna (2003) observes that a newspaper publisher can coerce an editor to write an editorial in a manner that he wants. This makes media owners, and not the editors, the 'ultimate gatekeepers.' That is the reason some media owners can hire and fire reporters and editors at the slightest whim (Omenugha et al, 2013). But editors who are not comfortable working under such restraining conditions are at liberty to leave. Uko (2002) cites an instance when several senior editors resigned from the then Concord Group of newspapers between 1984 and 1985, to establish their own titles. This followed the disagreement they had with the publisher, Moshood Abiola, a politician and a businessman, over editorial independence.

\subsection{The Media and the 'Sacred Cows' Syndrome}

It is difficult for journalists to be objective in their reports when their proprietors have a 'list' of persons and organisations that should not be touched. The proprietor's political party, associates, family and friends are often regarded as 'sacred cows.' Reporters often lament how their editors 'killed' good stories that they wrote, because such articles were considered not to be in the best interest of their employers. Those who are deemed to be too obstinate are often deployed to 'boring' beats as punishment. Ojebode (2013) says that such newspaper owners often coerce their editors into reporting the activities of their politician friends positively, while reporting those of their opponents negatively. But it is not all media houses that compromise their integrity. The Guardian Newspaper is an example of such a media organisation that still maintains its editorial independence. The publication demonstrated objectivity in its report of the arrest and trial of the proprietor's sister-in-law, who was then an influential managing director of a bank, over her financial peccadilloes. It may be argued that The Guardian can do this because it is not owned by a politician or a businessman with vested interests.

It is worth stating that the 1999 Constitution of the Federal Republic of Nigeria guarantees freedom of expression, and of the press. This, theoretically, gives the press the freedom to publish their stories without interference. Similarly, the Freedom of Information (FOI) Act that expresident Jonathan signed into law in 2011, is designed to guarantee Nigerians right to public information. But, in practice, this is not often the case.

\subsection{Influence of Newspaper Ownership on Elections}

The 2015 presidential election in Nigeria showed how influential newspaper owners can be when they choose to promote some candidates and malign the others, using the power of the press. PBOs practically used the media at their disposal to launch vitriolic attacks on their candidates' opponents during the elections. Petersen (1993) agrees that newspaper owners seem to possess great powers in society and over the editors and reporters. It 
is important to state that it is not only in Nigeria that newspapers influence the outcome of elections. Whitington (1977) also reports how the owner of Australia's Daily Telegraph, Frank Packer, instructed reporters covering the country's electoral campaign in 1943, to praise his choice of candidate, who happened to be the then Prime Minister, and to criticise his opponents. This shows that media ownership can play an important role in the editorial direction of a newspaper. Uko (2002) supports the assertion that a publisher's orientation has serious implications and valuable lessons for media practice.

The Nigerian presidential election, which is the focus of this work, is not different from the one held in Australia, as some politicians and businessmen used their ownership of media houses to project their candidates with the aim of safeguarding their political and economic interests. However, unlike in Nigeria, where there is multiplicity of media ownership, Uko (2002) observes that proprietorship is concentrated in a few hands in Australia. Just two newspaper chains publish approximately 90 percent of the national daily newspapers in Australia (Henningham, 1996). Cryle (1989) who also amplifies this fact, notes that few individuals and families have controlled newspapers in Australia, for centuries. Concentration of media ownership in a few hands has several implications. According to Anaeto et al (2007) this makes such media proprietors so powerful that they begin to oppress the weak in society. This happens due to the near monopoly that media owners enjoy. Media monopoly stifles plurality of opinion, which is not good for democracy.

\subsection{Statement of the Problem}

Newspaper ownership in Nigeria is often driven by political considerations rather than the desire to make revenue (Ibraheem et al, 2013). Ordinarily, the latter should have been the reason an investor would put down his money to set up a newspaper. That is the reason owners of PBO newspapers can dictate the stories that will be published and those that will not (Ojebode, 2013). In effect, the owners end up becoming the 'gatekeepers' themselves, rather than the editors. This poses an ethical dilemma for journalists working for such newspapers as they are often torn between their commitments to professionalism, and promoting the interests of their employers.

For example, focusing on PBO newspapers, Ojebode (2013) attempts to evaluate the influence of allegiance to the publisher's interests on the editorial independence of some Nigerian newspapers. Using textual analysis, Ojebode (2013) finds that journalists in PBO newspapers encounter difficulties in reporting facts accurately. This conflict arises because many journalists find themselves in a dilemma of having to choose between professionalism, and satisfying the interests of their proprietors. In this case, there appears to be some form of conflict between the libertarian theory, which 
advocates absolute freedom of the press, and the authoritarian theory that gives proprietors absolute powers of media control (Siebert et al, 1956). Under such circumstances, it may be challenging for journalists working for PBO newspapers to be objective in their report. This is the problem that the study seeks to address. Objectivity, in this context, will be measured or determined in terms of balanced and fair reportage that takes the views of the opposing parties into consideration. The goal of the paper will be to analyse the content of some PBO newspapers to find out the extent to which ownership influenced editorial direction in the coverage of the 2015 presidential election in Nigeria.

\subsection{Research Objectives} objectives:

Based on the identified problem, the study has the following

1. To find out if PBO newspapers equitably covered the 26 political candidates and their parties during the 2015 presidential election in Nigeria

2. To explore the extent to which such newspapers complied with ethical standards by managing conflict-sensitivity reporting

3. To ascertain whether their use of language de(escalated) violence

\subsection{Research Questions}

The assumptions or questions that will be tested in the study include the following:

1. Did PBO newspapers equitably cover the 26 political candidates and their parties during the 2015 presidential election in Nigeria?

2. To what extent did such newspapers comply with ethical standards by managing conflict- sensitivity reporting?

3. Did they de(escalate) violence with their use of language?

\subsection{Theoretical Framework}

There are several theoretical constructs that are used to explain media behaviour. These theories have some assumptions that can be used as a framework in this regard. Although the paper focuses on the gatekeeping theory because it is concerned with information management, it will also refer to other apposite theories to support its arguments.

The gatekeeping theory propounded by Kurt Lewin in 1943 looks at the process through which information is filtered for dissemination in a media organisation (Stacks and Salwen, 1996). In a typical newsroom, for instance, gatekeeping takes place in several ways and involves reporters, sub-editors, news editors, and editors. Gatekeeping also involves media outlet owners and even advertisers. For example, the Advertising Practitioners Council of Nigeria (APCON) usually vets all adverts before they are aired, thus serving 
as a gatekeeper. In a nutshell, the gatekeeper decides which information will be published and which will not, in the interest of society. But media owners, who are not professionals, dictated the stories editors should publish and what they should not publish, during the 2015 presidential election, thus circumventing the concept of gatekeeping. That is the reason there was no equitable coverage of all the 26 political parties in the country.

The source credibility theory propounded by Hovland, Janis, and Kelley in 1953 is also relevant to this discussion. The theory pertains to how the credibility of information source, determines whether or not people accept a report to be true. People are more likely to be persuaded to accept a story, when they perceive the source to be credible. Some media organisations are not deemed to be credible due to apparent ownership influence. Potter (2006) observes that when credibility suffers, a news organisation's ability to survive economically also does. This may reflect in poor sales and dwindling advertising revenue. Similarly, in a comparative analysis on the consequence of unethical behaviours among journalists, Wilmot (2006) states that when journalists lie, they threaten entire society. Sharing the same perspective, Day (2006) recalls that in 1985, 65 percent of the public believe news organisations typically got their fact right, noting that by 2002, the figure had declined to 35 percent. It is even likely to have nosedived further, 15 years later, given the current proliferation of newspapers that care little for ethics, but more for profits. This shows that the public are becoming increasingly sceptical of what they read in the newspapers nowadays. During the election campaign, Nigerian politicians used several newspapers to promote their propaganda, which often bordered on the sensational. However, the electorate believed only stories published by newspapers that are perceived to have strong editorial independence, while they cast aspersions on newspapers whose owners are thought to have sympathies for some political parties. This latter group of newspapers are essentially the PBOs.

Another theory that is relevant to this discussion is the social responsibility theory. The theory prescribes ethical standards by which the media should operate as part of their unwritten obligations towards society. According to McQuail (2010) the main propositions of the theory include the following: the media have an obligation to society and media ownership is a public trust; news media should be truthful, accurate, fair, objective and relevant; the media should be free, but self-regulated; the media should follow agreed codes of ethics and professional conduct; and under some circumstances, government may need to intervene to safeguard public interest. However, some profit-minded media owners in Nigeria have no scruples about getting editors to publish news items that may not be in public interest.

For instance, Ayodele Fayose, the PDP governor of Ekiti state, published several stories and advertisements in the media during 
electioneering questioning the state of health of Buhari. Although Fayose's allegations against Buhari raised some ethical concerns, some newspapers still went ahead and published them, apparently for pecuniary gains. That shows the extent to which media ownership influenced the editorial judgements of newspapers during the election.

Although, the code of ethics for Nigerian journalists prescribes the highest professional and ethical standards for practitioners, unethical practices among the press seem to be on the increase (Semiu et al, 2012). Even though regulatory bodies such as the Nigerian Press Council (NPC), the Nigerian Union of Journalists (NUJ) and other professional associations exist to checkmate the excesses of journalists, their efforts appear to have yielded little fruit. It must be noted that the press is a part and parcel of society. Anything that affects society affects the press too. It is, therefore, necessary to consider the peculiar environment within which the press operates in Nigeria. For many months, some journalists go to work without receiving salaries. Under such circumstances, it is quite difficult to expect such journalists to be ethical in their conduct. Few can resist 'brown envelopes,' which is a pseudonym that denotes honorarium or - in some cases - outright bribes, given to journalists to ensure positive publicity for an individual or an organisation. Pratt (1988) and Frankena and Granrose (1974) view ethics as a moral issue for the media. Omole (2000) defines ethics as the shared normative values, which any society holds dear and are used to judge the behaviour or performance of any member of a society.

\subsection{Methodology}

This paper adopts content analysis of documentary evidence as methodology, using a detailed report of the 2015 elections that Njemanze and Arogundade (2015) jointly authored, as methodology. It also makes reference to a related study by Nwammuo et al (2015), and undertakes a comparative review of both studies to find their points of convergence or divergence. Before delving into these studies, it may be pertinent to define the term documentary evidence to set the tone for this discussion.

According to Macdonald and Tipton (1993, cited in Gilbert, 1993) documentary evidence means the use of documents in social research that offers an account of the social realm. Public archival materials, including those of the government, individuals, newspapers, magazines, radio, television, advertisements, posters, and photographs, are different kinds of documents that may be used in social research (Macdonald and Tipton, 1993). On the other hand, content analysis is a research technique that is used for the objective, systematic and quantitative description of the manifest content of communication (Berelson, 1952). Content analysis can also be qualitative (Mayring, 2000). Qualitative content analysis is an approach of empirical, 
methodological controlled analysis of texts within their context of communication, without rash quantification (Mayring, 2000). Macdonald (1987, in Hakim, 1987) concurs that content analysis is a research design used for evaluating documentary evidence. However, Macdonald and Tipton (1993) advise that documents should be carefully assessed based on their authenticity, credibility, representativeness and meaning, to ensure research validity.

In our own independent study, we also carry out an assessment of some Nigerian newspaper articles published between November 2014 and April 2015. The rationale for picking this timeframe is that it was the peak of electioneering in the country. Also, the justification for primarily using newspapers, while excluding other sources of documentary evidence, is informed by the need to limit the scope of study to enable an in depth analysis.

In the first work reviewed, Njemanze and Arogundade (2015) assessed the performance of the selected media organisations, prior to, during, and immediately after the elections, using five parameters namely: use of sources, conflict sensitivity, language use, coverage of issues and coverage of the election management body. Njemanze and Arogundade (2015) selected 22 national and regional newspapers, four online media and three social media platforms for the monitoring, based on criteria that include wide readership; diversity of ownership and editorial staff; and substantial coverage of political and electoral issues. They employed both quantitative and qualitative methodologies for the monitoring and the analysis of their findings. The quantitative aspect involved the analysis of number and percentage of the relevant reports according to their genre and format, in the selected media organisations. The genre had to do with whether the reports were published as news, features, investigations, interviews, opinions, columns/articles, photographs and cartoons. The format consisted of the placement of the reports; whether they were reported on the front page, inside page, the editorial page or back page and space allocated. The qualitative dimension entailed the analysis of the content of reports to determine the focus, tone, professionalism and ethical standard of reporting.

Similarly, Nwammuo et al (2015) adopt content analysis as research method, using all newspapers published in Nigeria from December 2014 to April 2015, as the universe of the study. However, Nwammuo et al (2015) restrict their analyses to only the news stories published in December 2014, February 2015, March 2015 and April 2015, on the 2015 general elections in Nigeria. They also restricted the number of newspapers to four. According to Nwammuo et al (2015) the newspapers are in two categories: Vanguard and The Guardian newspapers (owned by businessmen) and The Sun and The Nation newspapers (owned by politicians). In total, they analysed 6,398 stories obtained from 92 copies of the four dailies. 
Nwammuo et al (2015) use the following criteria to evaluate the coverage inclination of the newspapers: direction of coverage (in terms of being neutral or negative); prominence/ placement of political stories (whether stories are on the front page, back page or inside page) and purpose of the story (determined by their ability to educate, influence, or castigate any political candidate or party). Nwammuo et al (2015) then analysed the data generated from the study quantitatively.

Also in his study, Ojebode (2013) adopts the use of in-depth interviews methodology with selected journalists in PBO media houses, to evaluate how much influence ownership has on editorial independence. Citing several scholars including Karppinen (2007); Jacka (2003); and Habermas (1995), Ojebode (2013) contends that the presence of a free press is one of the key characteristics of democracy. In the case of Nigeria, the media are far from being free to practice their profession due to the influence of media owners (Ojebode, 2013). Sparks (1992) reinforces this view by asserting that media independence may be difficult to achieve as there is hardly anywhere in the world where owners of newspapers do not wield some sort of influence. That is why politicians and businessmen who had a stake in the 2015 Nigerian elections used the newspapers that they control as a weapon to achieve their aims.

But political interference in journalism, is not peculiar to Nigeria alone. For instance, Ojebode (2013) cites the case of former Italian Prime Minister, Silvio Berlusconi, who appears to owe his political and business success to the media that he controls. Berlusconi, who is Italy's wealthiest man, controls almost 90 percent of Italian national television, two national newspapers and several large-circulating news magazines, and 60 percent of all television advertising sales (Ragnedda and Muschert, 2010). Evidently, this confers near absolute power on Berlusconi with regard to information control. In fact, some people have attributed his ability to wriggle out of numerous scandals to his firm control of a large proportion of the press in that country (Ragnedda and Muschert, 2010; Ginsborg, 2005). Although, no politician or businessman has such total control of the media in Nigeria, Berlusconi's case shows what can happen if this becomes a reality.

To determine the veracity of these claims, we conducted a new research of our own, adopting content analysis of newspapers, as our methodology. We used both newspapers that are sympathetic to the ruling party and the opposition parties, to ensure objectivity, measured in terms of balance of the stories.

\subsection{Findings}

According to Njemanze and Arogundade (2015) the different media organisations exhibited different levels of professionalism while reporting the 
activities of the political parties and candidates. Media organisations made noticeable efforts to comply with the legislative and institutional frameworks of media coverage of election, but there were significant areas of noncompliance (Njemanze and Arogundade, 2015). For instance, it was observed that the media were not sufficiently critical in analysing the campaign promises made by parties or their candidates. There was absence of rigorous analysis of the manifestoes of the political parties to highlight their areas of focus and strategies (Njemanze and Arogundade, 2015).

Looking at the first objective of this study which borders on whether PBO newspapers equitably reported political campaigns during the 2015 presidential elections, Njemanze and Arogundade (2015) observe that though 26 political parties were listed on the website of the Independent National Electoral Commission (INEC), only two parties-APC and PDP-got the most mention. Specifically, the report stated that out of 8,318 times that newspapers used political parties as sources within the review period (November 2014 to April 2015), the APC got the highest mention with 3,911 or (47.01 percent), closely followed by PDP with 3,716 or (44.67 percent). The 24 other parties shared the remaining 8.4 percent, while a significant number did not receive any mention.

This contravenes the Nigerian Media Code of Election Coverage, in section 1.1, sub-section ii, which states that a media organisation shall regularly apply the principle of equity in the coverage and reporting of campaigns and other activities of parties and candidates contesting elections. The document also found that the newspapers with the highest number of reports on political issues are Leadership and The Nation, both of which are PBOs. In addition, the political party that got the most mention, which is the APC, emerged the overall winner of the general elections (Njemanze and Arogundade, 2015).

The second objective had to do with the issue of conflict-sensitivity and this includes whether media reports give enough alert about possible outbreak of violence, and whether or not, they used sensational headlines that could inflame passion or instigate people into violence. The Nigerian Media Code of Election Coverage, in section 5.0 sub-section 1.8, specifically states that a media organisation shall refrain from the use of headlines that might inflame passion or cause disharmony. According to Njemanze and Arogundade (2015), the national dailies published 498 reports warning of impending dangers and likely issues that could result into violence in the review period.

The third objective relates to the use of language, which includes hate speeches and incitements. The Nigerian Media Code of Election Coverage, in section 4 sub-section 1.3, states that a media organisation shall reject any material intended for publication or airing by parties, candidates and other 
interests that contain hateful or inciting words and messages. Sub-section 1.4 adds that a media organisation shall refrain from publishing or airing abusive editorial comments or opinions that denigrate individuals or groups on account of disability, race, ethnicity, tribe, gender or belief. According to Njemanze and Arogundade (2015) stories capable of inciting one section of the country against the other, were recorded 45 times during this monitoring period, while hate speech featured eight times, despite these provisions. The report also notes that 117 sensational headlines, incitement and hate speeches and stereotypes were recorded in the six-month period, across 12 selected national print media. Most of the words or expressions that constituted hatred or incitement, were used in political advertorials by some of the monitored media organisations, the report adds.

Njemanze and Arogundade (2015) add that some of these inciting /sensational headlines include the following: "... Voting Jonathan would doom democracy." (The Nation, February 15, 2015, backpage). "Instead of Buhari to become President of Nigeria, Nigeria would rather break"-Dr. Doyin Okupe (Leadership, January 19, 2015, p.19). These headlines taken from two PBOs had the potential of conflagrating issues.

Findings by Nwammuo et al (2015) also indicated that politicianowned newspapers protected the political interest of their financiers to a large extent; while businessmen-owned newspapers appear neutral in the coverage of the elections. Findings further showed that ownership structure influenced the amount of coverage given to the elections; newspapers owned by politicians devoted more space to the coverage of political stories than papers owned by businessmen who had a bias for economic stories (Nwammuo et al, 2015). But the findings of Ibrahim et al (2015) who also examined the outcome of the presidential election in their paper, demonstrated that in addition to newspaper ownership, fear, poverty, and insecurity, influenced the voting patterns of Nigerians, and ultimately the results, as well. This seems to suggest that newspaper ownership alone, did not determine the outcome of the election.

Our own separate findings based on our analyses of some national dailies showed that the 'change' mantra that the opposition party dangled before the electorate, tipped the scales in their favour. The opposition used every available media including the social media, to propagate this message. We also find that the decision of the three main opposition parties in the country to form an alliance, proved to be the biggest determining factor that influenced the outcome of the election in their favour. Thus, beyond newspaper ownership, other factors determined the results of the 2015 general elections in Nigeria.

Our findings also agree to a large extent with that of Njemanze and Arogundade (2015). For instance, our analysis of the report on the front page 
of The Nation Newspaper of February 10, 2015, with the headline: PDP, military launch plan to rig polls, says Oyegun, shows that the story is capable of causing dissent. In the article, Professor John Odigie-Oyegun, the APC chairman, alleges that the greatest threat to Nigeria's democracy is the way the ruling party (PDP) has compromised the leadership of the Nigerian military to serve the personal agenda of Jonathan. He says this a 'dangerous game' and enjoins Nigerians to resist any attempt to rig the polls. The Nation, which is perceived to be an opposition paper, fails to reflect the views of the ruling party. This makes the article one-sided and defeats the notion of objectivity.

The Nation of March 27, 2015, also has some stories on its front page that are largely pro-APC. For instance, the lead story: Buhari: I am not in the race for money and power, leaves no room for doubt that The Nation is solidly behind Buhari, the APC presidential candidate, which it portrays as the right man the job. The newspaper also has this headline on the cover: Card readers' supplier held, how PDP plans to rig by APC. These headlines are obviously meant to cast aspersions on the ruling party and its candidate, the then incumbent President. The third story on the cover of the same edition: Jonathan versus Buhari: How States will vote, also displays lack of fairness, as the newspaper 'predicts' that Buhari will secure outright victory in 21 States, as against Jonathan's seven States, while it designates nine other States as 'battleground.'

We also find that newspapers sympathetic to the ruling party, equally displayed some bias in their coverage of the electioneering. For instance, Daily Sun Newspapers owned by Orji Uzor Kalu, a staunch member of the PDP, caused national outrage when it published Ekiti State Governor, Ayodele Fayose's 'death' advert on Buhari on the front page in its January 19, 2015 edition. The publication in question appears to suggest that Buhari, who was 72 years old then, might die in office if Nigerians vote him in as President. The advert, which Fayose allegedly sponsored, is considered one of the lowest moments of the 2015 presidential election campaign. Many individuals and organisations including the ruling party itself, condemned the advert. Some political analysts attribute the PDP's defeat during the elections to the numerous hate campaigns orchestrated by its members. We share these sentiments to an extent. This clearly demonstrates that newspaper owners influence the editorial thrust of their various publications. This trend played out quite well during the election.

But The Guardian Newspaper demonstrates neutrality while reporting stories on the elections. For instance, in its March 28, 2015 cover edition, The Guardian has this headline: Who Wins Today? Jonathan Or Buhari? The publication presents a balanced view on the chances of the two candidates at the election, which it notes will be a keen contest. It adds that given the groundswell of support both candidates enjoy there may be no landslide 
victory. It further observes that no presidential election has been so close to call since the advent of the Fourth Republic in 1999. Compared to the above report by The Nation, published the previous day, The Guardian's account seems to be a more objective report that does not favour any candidate. The Guardian can maintain equity in its reportage because of its ownership structure, which gives the publication room for editorial independence. That is why The Guardian remains one of the most credible newspapers in Nigeria today.

Based on their findings, Njemanze and Arogundade (2015) recommend that the media should in future elections, guarantee fair access and equitable coverage for all registered political parties to enable the electorate to make informed choices at the polls. They also called on regulatory agencies such as NPC and NBC, to strengthen and enforce their industry regulatory instruments, including election guidelines and professional conduct, to ensure media organisations deliver on equitable coverage of all political parties. Similarly, Nwammuo et al (2015) also recommend that Nigerian journalists should be objective in their coverage of issues, despite pressure from their proprietors, in line with the ethics of the profession. From these findings, there seems to be a correlation between the ownership structure of newspapers and the objectivity of their editorial content during the election.

\subsection{Conclusion}

This work has so far examined the media ownership structure in Nigeria and how it influences objectivity of newspaper reports, using two main studies on the 2015 elections in Nigeria, as a fulcrum to anchor the discussions. It defined objectivity to mean a balanced style of reporting that takes the views of all sides into consideration. While trying to do this, the paper traced the evolution of newspapers in Nigeria from pre-independence to postindependence, and it submitted that the ideologies of the owners in the two ages, are markedly different. The paper also stated that media control by politicians and businessmen, raises some ethical issues, as demonstrated during electioneering in the 2015 presidential election in Nigeria.

\subsection{Recommendations}

Based on its findings, this paper recommends that stakeholders in the Nigerian media industry must continue to place emphasis on journalism ethics because this is the only way journalists can truly gain the respect of society that they serve as watchdogs. It also recommends sweeping reforms in the media industry to weed out the bad eggs that have tainted the image of the profession. This is the age of developmental journalism and Nigerian journalists should join hands in making society a better place for all. But most importantly, this paper strongly recommends the need to ensure proper 
regulation of media ownership in Nigeria to reduce disproportionate concentration of power in the hands of a few wealthy and influential politicians and businesspersons, who use the press as a weapon to protect their interests.

\section{References:}

1. Berelson, B. (1952). Content analysis in communication research. Glencoe: Free Press.

2. Cryle, D. (1989). The press in colonial Queensland: A social and political history 1845 - 1875, Brisbane: University of Queensland Press.

3. Day, A. L. (2006). Ethics in media communication: Cases and controversies. 5th ed, USA: Thompson Higher Education.

4. Durotoye, A. (2015). Nigeria's 2015 presidential election: Between democratic consolidation change. European Scientific Journal. 11 (19).

5. Frankena, W.K. \&Granrose J.T. (1974). Introductory readings in ethics. New Online Journal of Communication and Media Technologies. 2 (4).

6. Ginsborg, P. (2005). Silvio Berlusconi: Television, power and patrimony. New York: Verso Books.

7. Habermas, J. (1995). Moral consciousness and communicative action. Cambridge: Polity Press.

8. Henningham, J. \& Delano, A. (1996). The news breed: British journalism in the 1990s. St Lucia: University of Queensland Press.

9. Ibraheem, I.A. Ayedun-Aluma, V. \& Adewoye, O.A. (2013). Power asymmetries and political communication in Nigeria: Challenging mainstream model of journalism practice. Paper presented at the Rethinking Media and Journalism Practice Conference at the University of Winchester, United Kingdom.

10. Ibrahim, S.G., Liman, A.N., \& Mato, K. (2015). The 2015 general elections: A review of major determinants of paradigm shift in voting behaviour and political participation in Nigeria. International Journal of Research in Humanities and Social Studies, 2 (9), 8-16.

11. Jacka, E. (2003). Democracy as defeat: The impotence of arguments for public service broadcasting. Television \& New Media, 4(2), 177-91.

12. Karppinen, K. (2007). Against naïve pluralism in media politics: On the implications of the Radical-pluralist approach to the public sphere. Media, Culture \& Society, 29 (3), 495-508.

13. Macdonald, K. \& Tipton, T. (1993). In Gilbert N (ed.) (1993). Researching social life. London: SAGE Publications. 
14. Macdonald, K. (1987). Research design: Strategies and choices in the design of social research, in Hakim, C. (1987). London: Routledge.

15. Mayring, P. (2000). Qualitative content analysis. Forum Qualitative Sozialforschung / Forum: Qualitative Social Research, 1(2), 20.

16. McQuail, D. (2010). Mass communication theory: An introduction (5th ed.). London: Sage Publications.

17. Njemanze, N. \& Arogundade, L. (2015). Reportage of 2015 elections: A monitoring scorecard of print and online media. The International Press Council (IPC) and the Nigerian Press Council (NPC).

18. Nwammuo, A.N, Edegoh, L.O.N \& Iwok, U. (2015). Nigerian press coverage of the 2015 elections: What has ownership got to do with it? International Journal of African and Asian Studies, 14, 81-88

19. Ojebode, A. (2013). Ethical dilemma revisited: PBO newspapers and the professional elbowroom of the Nigerian journalist. Journal of African Media Studies, 5 (3), 295-312.

20. Omenugha, K.A, Uzuegbunam, C.E, \& Omenugha, C. N. (2013). Good governance and media ownership in Nigeria: Dilemmatic practices, stoic challenges. Global Media Journal African Edition. $7(2), 92-115$.

21. Omole, G. (2000). The place of the Nigerian press council in ethics and regulations formulation: A working agenda for journalists and the media. Press Center International.

22. Owen, O. \& Usman, Z, (2015). Briefing: Why Goodluck Jonathan lost the Nigerian presidential election of 2015. African Affairs, Oxford University Press, 114 (456), 455-471.

23. Petersen, N. (1993). News not views - The ABC, the press \& politics 1932 -1947. Sydney: Hale \& Iremonger.

24. Potter, D. (2006). Handbook on independent journalism. Washington DC: US Department of State, International Programs.

25. Pratt, C. B. (1988). Responsibility and ethical reasoning in the Nigerian Press. African Media Review. 2 (2).

26. Ragnedda, M. \& Muschert, G. W. (2010). The political use of fear and news reporting in Italy: The case of Berlusconi's media control. Journal of Communication Research. 2 (1), 1-12.

27. Stacks, D.W. \& Salwen, M.B. (Eds). An Integrated Approach to Communication Theory, and Research (2nd ed., pp. 79-97). New York: Routledge.

28. Semiu, B. Aminat, A. \& Folarin, J. (2012). Unethical practices among journalists and the Nigerian public sphere. Online Journal of Communication and Media Technologies. 2(4).

29. Siebert, F. S., Peterson, T. \& Schramm, W. (1956). Four theories of the press. Chicago: University of Illinois Press. 
30. Sparks, C. (1992). The press, the market and democracy. Journal of Communication. 42(1), 36-51.

31. Uko, N. (2002). History and the press: A case study of Australia and Nigeria. James Cook University. Cairns. Electronic Journal of Multidisciplinary Studies in the Tropics. 11 (2).

32. Whitington, D, (1977). Strive to be fair: An unfinished biography. Canberra: Australian National University Press.

33. Wilmot, P. (2006). Broadcasting, agenda setting and the integrity question. Abuja: The News Magazine. 